\title{
Dynamics of anti-SARS-CoV-2 IgG Antibodies Post- COVID-19 in a Brazilian Amazon Population
}

\section{Carlos David Araújo Bichara}

Amaral Costa Diagnostic Medicine

\section{Ednelza da Silva Graça Amoras}

Federal University of Para

Gergiane Lopes Vaz

Amaral Costa Diagnostic Medicine

Maria Karoliny da Silva Torres

Federal University of Para

Maria Alice Freitas Queiroz

Federal University of Para

Isabella Pinheiro Costa do Amaral

Amaral Costa Diagnostic Medicine

Izaura Maria Vieira Cayres Vallinoto

Federal University of Para

Cléa Nazaré Carneiro Bichara

State University of Pará

Antonio Carlos Rosário Vallinoto ( $\nabla$ vallinoto@ufpa.br)

Federal University of Para

\section{Research Article}

Keywords: COVID-19, SARS-CoV-2, IgG, Amazon

Posted Date: February 23rd, 2021

DOl: https://doi.org/10.21203/rs.3.rs-228739/v1

License: (c) (i) This work is licensed under a Creative Commons Attribution 4.0 International License.

Read Full License 


\section{Abstract}

Background: In this study, the prevalence and persistence of anti-SARS-CoV-2 (severe acute respiratory syndrome-coronavirus) IgG was evaluated in volunteers 90 days after COVID-19 (coronavirus disease 2019) diagnosis by correlating response dynamics with clinical conditions, IL-1 $\beta$ and IL-6 cytokine levels, epidemiological characteristics, and disease severity.

Methods: The study recruited 200 volunteers aged 18 years or older of both sexes diagnosed with COVID19. ELISA testing was performed to detect IgG persistence and cytokine levels in 135 individuals with a previous serological test at the time of COVID-19 diagnosis.

Results: Among the 135 individuals who underwent a previous serological test for anti-SARS-CoV-2 antibody and provided a new blood sample 90 days after the first examination, 125 showed reactivity to IgG (92.6\%). Of the 125 individuals with detectable lgG in the first test, $69.6 \%$ showed persistence of this antibody after 90 days; however, in 10 (30.4\%) individuals, IgG was nonreactive in the second evaluation. The frequency of all reported symptoms was higher in individuals who maintained IgG persistence after 90 days of symptoms, and no relationship with cytokine levels was observed.

Conclusions: The results of the present study show a high frequency of loss of anti-SARS-CoV-2 IgG antibodies within three months after COVID-19 diagnosis in the Brazilian Amazon.

\section{Background}

The pandemic caused by SARS-CoV-2 (severe acute respiratory syndrome-coronavirus) spread worldwide in early 2020, causing millions of cases and deaths due to COVID-19 (coronavirus disease 2019) [1]. COVID-19 is characterized by several signs and symptoms, including fever, dry cough, dyspnea, headache, chest pain, myalgia, fatigue, nausea, vomiting, diarrhea, abdominal pain, pulmonary infiltrates with fibrosis, and a decreased peripheral lymphocyte count, and may progress to severe acute respiratory syndrome (SARS) [2].

Several aspects have been investigated to clarify differences regarding the clinical evolution of patients with COVID-19 [3-5]. To date, advanced age and the presence of comorbidities are the main factors associated with disease severity [6]. Immune responses have also been evaluated in terms of both cellular and humoral responses [7-9]. In terms of humoral responses, the production of antibodies against SARS-CoV-2 has been widely investigated by relating their presence to the pathogenesis of COVID-19 or protection against reinfection $[10,11]$.

Evaluations of the antibody response dynamics for the SARS-CoV species have shown the possibility of variation in the time of IgG seroconversion. Some patients may present late seroconversion of this antibody isotype; that is, seroconversion may occur more than 21 days after the onset of disease symptoms [12]. In this type of infection, IgG levels seem to be related to SARS progression [13]. 
The antibody-mediated response against SARS-CoV-2 is initially characterized by IgM production, which decreases from the third week, while the IgG response is maintained in patients with COVID-19. In addition, more intense $\operatorname{lgM}$ and $\mathrm{IgG}$ antibody responses seem to affect patients with severe cases of the disease. These dynamics of the IgG response for SARS-CoV-2 have been shown to be similar among coronavirus species [10].

Although advanced age and the presence of comorbidities are the main risk factors for the development of severe COVID-19, a significant number of individuals do not have these factors but develop severe forms of the disease [14]. Therefore, evaluating the relationships of established risk factors with the effect of the immune response, including the production and dynamics of antibodies, may better elucidate the evolution of COVID-19. Thus, the present study evaluated the prevalence and persistence of IgG in patients in the acute phase of COVID-19 and 90 days after disease diagnosis by correlating these dynamics with clinical conditions, epidemiological characteristics, and COVID-19 severity.

\section{Methods}

\section{Study population}

In this observational cross-sectional study, 200 individuals of both sexes with a previous diagnosis of COVID-19 were selected. The inclusion criteria were age equal to or greater than 18 years, a diagnosis of COVID-19, and residency in the metropolitan region of the city of Belém, the capital of the State of Pará, Brazilian Amazon.

The study participants were selected after advertisement of the research through social media and voluntarily agreed to participate in the study. The volunteers completed a questionnaire designed to collect demographic and social data and information regarding the risk for SARS-CoV-2 infection. Furthermore, clinical and laboratory data were collected. The following tests were considered diagnostic confirmation criteria for COVID-19: IgG-reactive serology, RT-qPCR detection, or chest computed tomography (CT).

One hundred thirty-five of 200 volunteers with a previous serological test for anti-SARS-CoV-2 antibodies who agreed to participate in the study were invited to provide a new blood sample at the Amaral Costa Diagnostic Laboratory 90 days after the first test at the time of diagnosis.

\section{Complementary laboratory and imaging tests}

Information from the first serological test for anti-SARS-CoV-2 IgG, RT-qPCR molecular biology tests for SARS-CoV-2, and chest CT was obtained and transcribed from the diagnostic reports for each patient. Chest CT was used to assess pulmonary findings suggestive of COVID-19, such as ground-glass opacities and sparse bilateral foci of consolidation, predominantly in the peripheral regions, and the extent of pulmonary involvement was classified as mild (<25\%), moderate $(25-50 \%)$, or severe $(>50 \%)$.

\section{Sample collection and detection of anti-SARS-COV-2 IgG}


Blood samples from all participants were collected in vacuum tubes containing separator gel, and serum was isolated by centrifugation and stored at $-20^{\circ} \mathrm{C}$ until anti-SARS-CoV-2 IgG antibody testing, which was performed by qualitative chemiluminescent microparticle immunoassay (CMIA) in an Alinity i automated system (Abbott Laboratories, Chicago, IL, USA) following the manufacturer's protocol.

\section{Measurement of IL-1 $\beta$ and IL- 6}

Serological quantification of cytokines was performed only for samples from individuals 90 days after diagnosis of COVID-19. Enzyme-linked immunosorbent assays (ELISAs), the Human IL-6 Quantikine ELISA Kit, and the Human interleukin 1 Beta (IL-1 $\beta$ ) ELISA Kit (R\&D Systems, Minneapolis, MN, USA), which contain specific monoclonal antibodies, were used to detect each cytokine. The tests were performed according to the manufacturer's instructions.

\section{Statistical analysis}

All data were stored in a database created in Microsoft Excel, version 2020. Statistical analysis of the data was performed in BioEstat version 5.3. The qualitative data were analyzed using the chi-squared test, Fisher's exact test, and the $\mathrm{G}$ test, and differences were considered statistically significant when the $p$-value was $<0.05$.

\section{Results}

The study population consisted mostly of women (65.6\%) aged between 19 and 102 years but predominantly younger than 60 years $(75.1 \%)$. Most of the COVID-19 diagnoses were established by SARS-CoV-2 serological tests $(27.0 \%)$, followed by chest CT $(18.0 \%)$ or these two methods combined with RT-PCR (15.3\%). More than $95 \%$ of the study population consisted of symptomatic individuals with a symptom duration $\geq 21$ days, with only $8 \%$ reporting hospitalization and supplemental oxygenation use. The most prevalent blood group was type " 0 " (44.5\%), and most volunteers were immunized against H1N1 (83.0\%) and tuberculosis (85.0\%).

Among the 200 volunteers in the study, 114 underwent chest CT to assess the extent of lung damage, $65.8 \%$ of whom had mild pulmonary impairment, while $21 \%$ had moderate pulmonary impairment, and $6.1 \%$ had severe pulmonary impairment. A normal appearance of the lungs was reported for $7.9 \%$ of the volunteers (Table 1). 
Table 1

Demographic and clinical laboratory data of the study population

$\mathrm{n}(\%)$

\section{Sex}

Female

$132(65.6)$

Male

$68(34.4)$

Age

$<60$ years old (mean)

$150(75.1)$

$\geq 60$ years old (mean)

$50(24.9)$

Diagnosis of Covid-19

PCR

20 (8.4)

CT

35 (18.0)

Serology

55 (27.0)

$\mathrm{PCR}+\mathrm{CT}+\mathrm{SEROL}$

29 (15.3)

$\mathrm{PCR}+\mathrm{CT}$

$14(6.9)$

$\mathrm{PCR}+\mathrm{SEROL}$

$12(6.9)$

CT + SEROL

35 (17.5)

\section{Symptoms}

Yes

197 (98.5)

No

$3(1.5)$

\section{Duration of symptoms}

$\leq 7$ days

58 (29.4)

15 days

69 (35.0)

$\geq 21$ days

70 (35.6)

\section{Hospitalization}

Yes

$16(8.0)$

No

$184(92.0)$

\section{Supplemental oxygen}

PCR: Polymerase chain reaction; CT: Computed tomography; SEROL: Serology 


\begin{tabular}{|ll|}
\hline & $\mathbf{n}(\%)$ \\
\hline Yes & $16(8.0)$ \\
\hline Blood type (ABO) & $184(92.0)$ \\
\hline A & \\
\hline B & $55(27.5)$ \\
\hline AB & $12(6.0)$ \\
\hline O & $5(2.5)$ \\
\hline Unknown & $89(44.5)$ \\
\hline H1N1 vaccine & $39(19.5)$ \\
\hline Yes & $166(83.0)$ \\
\hline No & $34(17.0)$ \\
\hline BCG vaccine & \\
\hline Yes & $170(85.0)$ \\
\hline No & $17(8.5)$ \\
\hline Unknown & $13(6.5)$ \\
\hline Pulmonary involvement & \\
\hline Normal & $9(7.9)$ \\
\hline Mild (<25\%) & \\
\hline Moderate (25 to 50\%) & \\
\hline Severe (> 50\%) & \\
\hline PCR: Polymerase chain reaction; CT: Computed tomography; SEROL: Serology \\
\hline
\end{tabular}

One hundred thirty-five volunteers received the SARS-CoV-2 IgG test at the time of COVID-19 symptom presentation, 125 of whom showed SARS-CoV-2 IgG reactivity (92.6\%). Among the individuals with SARSCoV-2-reactive IgG, the most frequently reported symptoms were anosmia, body pain, headache, ageusia, fever, cough, and shortness of breath. In the group without SARS-CoV-2-reactive IgG, the most reported symptoms were fever, sore throat, cough, headache, anosmia, and ageusia. A longer duration of symptoms ( $\geq 21$ days) was observed in the group with SARS-CoV-2-reactive IgG group than in the group 
without SARS-CoV-2-reactive IgG. However, no statistically significant difference in the frequency of symptoms was found between the two groups evaluated (Table 2).

Table 2

The frequency of symptoms in individuals with and without SARSCoV-2-reactive IgG at the time of diagnosis and the time of symptom onset

\begin{tabular}{|lllll|}
\hline Symptoms & \multicolumn{3}{c}{ 1st IgG test } & \multirow{2}{*}{ * $^{*}$} \\
\cline { 2 - 5 } & $\mathbf{N}$ & Reactive & Nonreactive & \\
& & $\mathbf{n}=125$ & $\mathbf{n = 1 0}$ & \\
\hline Fever & & $\mathbf{n}(\%)$ & $\mathbf{n}(\%)$ & \\
\hline Headache & 84 & $76(60.8)$ & $7(70.0)$ & 0.7405 \\
\hline Coryza & 94 & $88(70.4)$ & $6(60.0)$ & 0.4911 \\
\hline Cough & 62 & $59(47.2)$ & $3(30.0)$ & 0.3422 \\
\hline Sore throat & 85 & $79(63.2)$ & $6(60.0)$ & 0.9994 \\
\hline Body pain & 73 & $66(52.8)$ & $7(70.0)$ & 0.3422 \\
\hline Abdominal pain & 94 & $89(71.2)$ & $5(50.0)$ & 0.2818 \\
\hline Diarrhea & 32 & $32(25.6)$ & $0(0.0)$ & 0.1165 \\
\hline Vomiting & 62 & $58(46.4)$ & $4(40.0)$ & 0.7532 \\
\hline Nausea & 16 & $16(12.8)$ & $0(0.0)$ & 0.3681 \\
\hline Anosmia & 37 & $37(29.6)$ & $0(0.0)$ & 0.0614 \\
\hline Ageusia & 95 & $90(72.0)$ & $5(50.0)$ & 0.1640 \\
\hline Shortness of breath & 60 & $58(46.4)$ & $2(20.0)$ & 0.1843 \\
\hline Hair loss & 47 & $44(35.2)$ & $3(30.0)$ & 1.0000 \\
\hline Duration of symptoms & & & & 0.2939 \\
\hline S7 days & 43 & $40(32.0)$ & $3(30.0)$ & 1.0000 \\
\hline 15 days & 43 & $39(31.2)$ & $4(40.0)$ & 0.7253 \\
\hline$\geq 21$ days & 46 & $44(35.2)$ & $2(20.0)$ & 0.4936 \\
\hline No symptoms & 03 & $2(1.6)$ & $1(10.0)$ & 0.2073 \\
\hline *Fisher's exact test & & & & $5(50.0)$ \\
\hline
\end{tabular}


Of the 125 individuals with detectable IgG in the first test, $69.6 \%$ showed sustained detection of this antibody after 90 days; however, in 10 (30.4\%) individuals, SARS-CoV-2-reactive IgG was not detected in the second evaluation. Of the 10 individuals without SARS-CoV-2-reactive IgG in the second evaluation, $60 \%$ showed seroconversion based on the results from the first test, and $40 \%$ remained without detectable SARS-CoV-2-reactive lgG (Table 3).

Table 3

The frequency and persistence of SARS-CoV-2-reactive IgG in the study population 90 days after diagnosis

\begin{tabular}{|llll|}
\hline 1st IgG test & \multicolumn{2}{c|}{ 2nd IgG test } & \multirow{2}{*}{ * $^{*}$} \\
\cline { 2 - 3 } & $\begin{array}{l}\text { Reactive }(\mathrm{n}=93) \\
\mathrm{n}(\%)\end{array}$ & $\begin{array}{l}\text { Nonreactive }(\mathrm{n}=42) \\
\mathrm{n}(\%)\end{array}$ & \\
\hline Reactive $(\mathrm{n}=125)$ & $87(69.6)$ & $38(30.4)$ & 0.7846 \\
\hline Nonreactive $(\mathrm{n}=10)$ & $06(60.0)$ & $04(40.0)$ & \\
\hline$*$ G test & & & \\
\hline
\end{tabular}

Individuals with SARS-CoV-2-reactive lgG in the second evaluation were considered to have a persistent IgG response, and those without reactive tests were considered to have a nonpersistent IgG response.

Table 4 describes the characteristics of individuals with and without detectable SARS-CoV-reactive IgG 90 days after diagnosis. When comparing the two groups, both predominantly consisted of females $(64 \%$ and $70.5 \%$ with and without a persistent IgG response, respectively) with a mean age younger than 60 years (73.3\% and $85.3 \%$ with and without a persistent $\lg G$ response, respectively). However, the percentage of individuals aged $\geq 60$ years was more frequent in the group with a persistent IgG response than in the group without a persistent IgG response ( $26.7 \%$ and $14.7 \%$, respectively). A predominance of symptomatic individuals was noted in both groups ( $100 \%$ and $94.1 \%$ with and without a persistent IgG response, respectively), and symptom manifestations lasted $\geq 21$ days in the group with a persistent IgG response (39.6\%) and $\leq 7$ days in the group with a nonpersistent IgG response (50.0\%). The length of hospital stay and supplemental oxygen use were higher in individuals with a persistent lgG response (10.5\%). Regarding vaccination against H1N1 and Bacillus Calmette-Guérin (BCG), no differences were observed between the two groups ( $88.4 \%$ and $79.4 \%$ with and without a persistent IgG response, respectively). 
Table 4

Evaluation of epidemiological and clinical variables according to IgG persistence 90 days after diagnosis

\begin{tabular}{|c|c|c|c|c|}
\hline \multirow[t]{4}{*}{ Variables } & \multicolumn{3}{|c|}{ 2nd IgG test } & \multirow[t]{4}{*}{$p$} \\
\hline & \multirow[t]{3}{*}{$\mathbf{N}$} & Persistent & Nonpersistent & \\
\hline & & $\mathrm{n}=87$ & $n=38$ & \\
\hline & & $\mathrm{n}(\%)$ & $\mathrm{n}(\%)$ & \\
\hline \multicolumn{5}{|l|}{ Sex } \\
\hline Female & 83 & $56(64.0)$ & $27(70.5)$ & $0.6017 *$ \\
\hline Male & 42 & $31(36.0)$ & $11(29.5)$ & \\
\hline \multicolumn{5}{|l|}{ Age } \\
\hline$<60$ years old & 94 & $61(73.3)$ & $33(85.3)$ & $0.0773^{*}$ \\
\hline$\geq 60$ years old & 31 & $26(26.7)$ & $5(14.7)$ & \\
\hline \multicolumn{5}{|l|}{ Symptoms } \\
\hline Yes & 123 & $87(100)$ & $36(94.1)$ & $0.1902^{\star *}$ \\
\hline No & 02 & 0 & $2(5.9)$ & \\
\hline \multicolumn{5}{|c|}{ Duration of symptoms } \\
\hline$\leq 7$ days & 40 & $24(26.7)$ & $16(50.0)$ & $0.1424^{\star}$ \\
\hline 15 days & 39 & $28(33.7)$ & $11(29.4)$ & \\
\hline$\geq 21$ days & 44 & $35(39.6)$ & $9(20.6)$ & \\
\hline \multicolumn{5}{|l|}{ Hospitalization } \\
\hline Yes & 11 & $10(10.5)$ & $1(2.9)$ & $0.1756^{*}$ \\
\hline No & 114 & $77(89.5)$ & $37(97.1)$ & \\
\hline \multicolumn{5}{|c|}{ Supplemental oxygen } \\
\hline Yes & 11 & $10(10.5)$ & $1(2.9)$ & $0.1756^{\star \star}$ \\
\hline No & 114 & 77 (89.5) & $37(97.1)$ & \\
\hline \multicolumn{5}{|l|}{ H1N1 vaccine } \\
\hline Yes & 106 & $71(81.4)$ & $35(91.2)$ & $0.1997 * *$ \\
\hline No & 19 & 16 (18.6) & $3(8.8)$ & \\
\hline
\end{tabular}




\begin{tabular}{|lllll|}
\hline Variables & \multicolumn{3}{c|}{ 2nd IgG test } & p \\
\cline { 2 - 4 } & $\mathbf{N}$ & Persistent & Nonpersistent \\
& & $\mathbf{n}=\mathbf{8 7}$ & $\mathbf{n = 3 8}$ \\
& & $\mathbf{n}(\%)$ & $\mathbf{n}(\%)$ & \\
\hline BCG vaccine & & & & $0.6766^{* \star}$ \\
\hline Yes & 102 & $71(88.4)$ & $31(79.4)$ & \\
\hline No & 09 & $5(5.8)$ & $4(11.8)$ & \\
\hline Unknown & 08 & $5(5.8)$ & $3(8.8)$ & \\
\hline *Chi-squared test; **G test & & & \\
\hline
\end{tabular}

The frequency of all reported symptoms was higher in individuals who maintained a persistent IgG response 90 days after diagnosis than in those who presented a nonpersistent IgG response after the same period, but a statistically significant difference was observed only for the cough symptom ( $p=$ 0.0257) (Table 5). 
Table 5

Symptoms presented by individuals in the acute phase of COVID-19 according to $\operatorname{lgG}$ persistence 90 days after diagnosis

\begin{tabular}{|lllll|}
\hline Symptoms & \multicolumn{3}{c}{ 2nd IgG } & \multirow{2}{*}{$\boldsymbol{p}^{*}$} \\
\cline { 2 - 5 } & $\mathbf{N}$ & Persistent & Nonpersistent & \\
& & $\mathbf{n = 8 7}$ & $\mathbf{n = 3 8}$ \\
& & $\mathbf{n}(\%)$ & $\mathbf{n}(\%)$ & \\
\hline Fever & 80 & $60(69.0)$ & $20(52.6)$ & 0.1052 \\
\hline Headache & 89 & $63(72.4)$ & $26(68.4)$ & 0.6718 \\
\hline Coryza & 60 & $45(51.7)$ & $15(39.4)$ & 0.2453 \\
\hline Cough & 80 & $61(70.1)$ & $18(47.3)$ & 0.0257 \\
\hline Sore throat & 66 & $47(54.6)$ & $19(50.0)$ & 0.7011 \\
\hline Body pain & 90 & $66(75.8)$ & $24(63.1)$ & 0.1935 \\
\hline Abdominal pain & 32 & $26(29.8)$ & $6(15.8)$ & 0.1207 \\
\hline Diarrhea & 61 & $45(51.7)$ & $16(42.1)$ & 0.3385 \\
\hline Vomiting & 19 & $14(16.1)$ & $2(5.3)$ & 0.1448 \\
\hline Nausea & 37 & $30(34.4)$ & $7(18.2)$ & 0.0891 \\
\hline Anosmia & 90 & $66(75.9)$ & $24(63.2)$ & 0.3713 \\
\hline Ageusia & 86 & $63(72.4)$ & $23(60.5)$ & 0.8447 \\
\hline Shortness of breath & 60 & $46(52.8)$ & $14(36.8)$ & 0.1208 \\
\hline Hair loss & 47 & $36(41.0)$ & $11(28.9)$ & 0.2303 \\
\hline *Fisher's exact test & & & & \\
\hline
\end{tabular}

Of the 135 individuals who underwent SARS-CoV-2 lgG tests, only 67 underwent chest CT at the same time for lung assessment. Table 6 shows that all individuals with moderate and severe pulmonary involvement had SARS-CoV-2-reactive IgG and that most of these individuals (19/21) maintained a persistent IgG response after 90 days of infection. 
Table 6

Radiological parameters of pulmonary involvement according to IgG dynamics at the time of COVID-19 diagnosis and 90 days after diagnosis

\begin{tabular}{|c|c|c|c|c|c|c|c|}
\hline \multirow{2}{*}{$\begin{array}{l}\text { Pulmonary } \\
\text { involvement }\end{array}$} & \multicolumn{3}{|c|}{ 1st lgG test } & \multicolumn{3}{|c|}{ 2nd IgG test } & \multirow[b]{2}{*}{$\mathrm{p}^{*}$} \\
\hline & $\mathbf{N}$ & $\begin{array}{l}\text { Reactive } \\
\text { n (\%) }\end{array}$ & $\begin{array}{l}\text { Nonreactive } \\
\text { n (\%) }\end{array}$ & $\mathrm{p}^{*}$ & $\begin{array}{l}\text { Persistent } \\
\text { n (\%) }\end{array}$ & $\begin{array}{l}\text { Nonpersistent } \\
\mathrm{n}(\%)\end{array}$ & \\
\hline Normal & 8 & 7 (11.9) & $1(12.5)$ & 0.05 & $3(5.9)$ & 5 (31.2) & 0.02 \\
\hline Mild (<25\%) & 38 & $\begin{array}{l}31 \\
(52.5)\end{array}$ & 7 (87.5) & & $29(56.9)$ & $9(56.3)$ & \\
\hline $\begin{array}{l}\text { Moderate/severe } \\
\text { ( } 25 \text { to } 50 \% />50 \%)\end{array}$ & 21 & $\begin{array}{l}21 \\
(35.6)\end{array}$ & $0(0.0)$ & & 19 (37.2) & $2(12.5)$ & \\
\hline
\end{tabular}

The concentration curve of the standards used to measure IL-1 $\beta$ ranged from 7.78 to $101.14 \mathrm{pg} / \mathrm{mL}$, and the mean sample concentration was $7.72 \mathrm{pg} / \mathrm{mL}$. The concentration for IL- 6 quantification ranged from 5.53 to $75.3 \mathrm{pg} / \mathrm{mL}$, and the mean concentration was $5.55 \mathrm{pg} / \mathrm{mL}$ (data not shown).

\section{Discussion}

The population in the present study mostly consisted of women, which differs from the results observed in São Paulo (Brazil) and England where males were more frequent among those diagnosed with COVID$19[15,16]$. A higher COVID-19 mortality rate in males has also been described in 37 of the 38 countries that provide data by sex [17]. However, the effect of sex on SARS-CoV-2 infection still requires further investigation [18], and genetic, immunological, hormonal, sociobehavioral, economic, and lifestyle factors must be considered to identify such differences $[19,20]$.

More than $95 \%$ of the study population consisted of symptomatic individuals, most likely because individuals with symptoms suggestive of COVID-19 more frequently sought diagnostic laboratory services.

The humoral immune response has been described and suggested as fundamental for protection against SARS-CoV-2 [21, 22]. In addition, the kinetics of the emergence of anti-SARS-CoV-2 antibodies revealed the absence of seroconversion or even a loss of antibodies after infection [23, 24]. Patel et al. [25] reported the $42 \%$ and $58 \%$ of health professionals from Tennessee (USA) exhibited a persistent IgG response and a nonpersistent IgG response, respectively, 60 days after diagnosis. Robbiani et al. [21] concluded in their study with convalescent COVID-19 patients that many did not have high titers of neutralizing antibodies 39 days after symptom onset. Demonbreun et al. [26] observed loss of anti-SARSCoV-2 antibody seropositivity after 120 days in $25 \%$ of a cohort in Chicago (USA). 
The impact of this high percentage of individuals who lost detectable levels of circulating antibodies on the occurrence of SARS-CoV-2 reinfection remains unknown, as has been reported in some countries [27]. Considering that the response time of anti-SARS-CoV-2 antibodies seems to be short in a large portion of the population and that cellular immunity mediated by $T$ lymphocytes is important and lasting [28], Altmann \& Boyton [29] suggest that conducting population screening tests for anti-SARS-CoV-2 antibodies and $T$ cells would be very useful.

Most infected individuals generate antibody and $\mathrm{T}$ cell responses with magnitudes correlated with the time of infection and disease severity [30]. In this study, more than $95 \%$ of the individuals evaluated were symptomatic, with greater IgG persistence among those with symptoms lasting $\geq 21$ days and lower persistence among those with symptoms lasting $\leq 7$ days. The length of hospital stay, supplemental oxygen use, the number of reported symptoms, and moderate and severe pulmonary involvement were also more frequent in individuals with a persistent IgG response, indicating a close relationship between COVID-19 severity and the magnitude of the immune response, as previously suggested [29, 31]. Length of hospital stay and the quality and quantity of the antibody response may be associated with clinical manifestations and disease course, thus justifying further investigations [32].

The proinflammatory response plays an important role in the pathogenesis of COVID-19, especially in the development of more severe forms of the disease. At a more advanced stage of infection, cells secrete high levels of IL-1 $\beta$, IL-6, and tumor necrosis factor (TNF) [33]. In the present study, we evaluated whether individuals with a persistent IgG response had a sustained inflammatory response mediated by IL-1 $\beta$ and IL-6 90 days after diagnosis. The results showed that after 90 days, the individuals presented basal levels of cytokines, including those $(n=44)$ who reported experiencing post-COVID-19 symptoms (shortness of breath, anosmia, fatigue on exertion, hair loss, fatigue, dizziness, back pain, and muscle and joint pain). These findings demonstrate that although inflammatory cytokines are present at high levels in patients with COVID-19 admitted to hospitals [34], cytokine levels in individuals recovering from the disease do not persist 90 days after infection, even in patients who maintain symptoms related to COVID-19.

The percentage of individuals aged $\geq 60$ years was higher in the group with a persistent IgG response. Klein et al. (2020) showed that older age was associated with increased antibody responses to COVID-19, which emerged as a factor that can be used to identify individuals with a high probability of presenting strong antiviral antibody responses [35] in contrast to other studies pointing to natural impairment of the immune response in the elderly population due to senescence [36, 37]. However, in addition to senescence, aging is accompanied by changes in the immune profile characterized by chronic subclinical systemic inflammation (inflamm-aging) that may contribute to the disproportionate SARS-CoV-2 mortality rate among elderly patients [38].

\section{Conclusions}

The observed results reveal relationships between female sex, age, symptom duration, and disease severity and the persistence and loss of serum IgG levels in individuals who have recovered from COVID- 
19 for the first time in the Brazilian Amazon region. The percentage of patients exhibiting antibody loss was high in the present study, which may have implications for seroepidemiological investigations [39], especially those conducted recently, possibly leading to underestimated calculations of the prevalence of infection or even the susceptibility of the population to possible reinfection and thus compromising the success of current vaccination campaigns.

\section{Abbreviations}

SARS-CoV-2: Severe acute respiratory syndrome-coronavirus; COVID-19: coronavirus disease 2019; SARS: Severe acute respiratory syndrome; IgG: Immunoglobulin G; IgM: Immunoglobulin M; CT: Computed tomography; RT-qPCR: Reverse transcription real-time polymerase chain reaction; CMIA: Chemiluminescent microparticle immunoassay; ELISAs: Enzyme-linked immunosorbent assays; IL-6: Interleukin-6; IL-1ß: Interleukin-1 beta.

\section{Declarations}

\section{Ethics approval and consent to participate}

This project was submitted to and approved by the Human Research Ethics Committee of the Institute of Health Sciences of the Federal University of Pará (CAAE: 31800720.1.0000.0018) in compliance with the guidelines and regulatory standards for research involving human beings. Individuals who agreed to participate in the study signed an informed consent form.

\section{Consent for publication}

Not applicable.

\section{Availability of data and materials}

Data are available upon request from the corresponding author.

\section{Competing interests}

The authors declare that they have no competing interests.

\section{Funding}

This project was funded by the National Council for Scientific and Technological Development (CNPq), the Ministry of Science, Technology and Innovation (MCTI), and the Ministry of Health (MS); Process CNPQ 401235/2020-3; Federal University of Pará - Support Program for Qualified Production (PAPQ2020).

\section{Authors' contributions}


ACRV and CDAB conceived the project. CDAB, IPCA, and GLV performed the laboratory analyses. CDAB, ESGA, MKST and MAFQ performed the statistical analyses and wrote the draft of the article. ACRV, CNCB, and IMVCV reviewed the article.

\section{Acknowledgments}

We thank all individuals who agreed to participate in this study.

\section{References}

1. WHO Coronavirus Disease (COVID-19) Dashboard. Available online: https://covid19.who.int/.

2. Wang Y, Wang Y, Chen Y, Qin Q. Unique epidemiological and clinical features of the emerging 2019 novel coronavirus pneumonia (COVID-19) implicate special control measures. J Med Virol. 2020;92:568-76. http://dx.doi.org/10.1002/jmv.25748.

3. Liu S, Luo H, Wang Y, Cuevas LE, Wang D, Ju S, Yang Y. Clinical characteristics and risk factors of patients with severe COVID-19 in Jiangsu province, China: a retrospective multicentre cohort study. BMC Infect Dis. 2020;20:584. http://dx.doi.org/10.1186/s12879-020-05314-x.

4. Klonoff DC, Umpierrez GE. Letter to the Editor: COVID-19 in patients with diabetes: Risk factors that increase morbidity. Metabolism. 2020;108:154224. http://dx.doi.org/10.1016/j.metabol.2020.

5. Hou Y, Zhao J, Martin W, Kallianpur A, Chung MK, Jehi L, et al. New insights into genetic susceptibility of COVID-19: an ACE2 and TMPRSS2 polymorphism analysis. BMC Med. 2020;18:216. http://dx.doi.org/10.1186/s12916-020-01673-z.

6. Zhang JJ, Dong X, Cao YY, Yuan YD, Yang YB, Yan YQ, et al. Clinical characteristics of 140 patients infected with SARS-CoV-2 in Wuhan, China. Allergy. 2020;75:1730-41. http://dx.doi.org/10.1111/all.14238.

7. Maggi E, Canonica GW, Moretta L. COVID-19: Unanswered questions on immune response and pathogenesis. J Allergy Clin Immunol. 2020;146:18-22. http://dx.doi.org/10.1016/j.jaci.2020.05.001.

8. Suhandynata RT, Hoffman MA, Kelner MJ, McLawhon RW, Reed SL, Fitzgerald RL. Longitudinal Monitoring of SARS-CoV-2 IgM and IgG Seropositivity to Detect COVID-19. J Appl Lab Med. 2020;5:908-20. http://dx.doi.org/doi: 10.1093/jalm/jfaa079.

9. Han H, Ma Q, Li C, Liu R, Zhao L, Wang W, et al. Profiling serum cytokines in COVID-19 patients reveals IL-6 and IL-10 are disease severity predictors. Emerg Microbes Infect. 2020;9:1123-30. http://dx.doi.org/10.1080/22221751.2020.

10. Liu X, Wang J, Xu X, Liao G, Chen Y, Hu CH. Patterns of IgG and IgM antibody response in COVID-19 patients. Emerg Microbes Infect. 2020;9:1269-74. http://dx.doi.org/10.1080/22221751.2020.1773324.

11. Bournazos S, Gupta A, Ravetch JV. The role of IgG Fc receptors in antibody-dependent enhancement. Nat Rev Immunol. 2020;20:633-43. http://dx.doi.org/10.1038/s41577-020-00410-0. 
12. Hsueh PR, Hsiao CH, Yeh SH, Wang WK, Chen PJ, Wang JT, et al. SARS Research Group of National Taiwan University College of Medicine and National Taiwan University Hospital. Microbiologic characteristics, serologic responses, and clinical manifestations in severe acute respiratory syndrome, Taiwan. Emerg Infect Dis. 2003;9:1163-7. http://dx.doi.org/10.3201/eid0909.030367.

13. Chang WT, Kao CL, Chung MY, Chen SC, Lin SJ, Chiang WC, et al. SARS exposure and emergency department workers. Emerg Infect Dis. 2004;10:1117-9. http://dx.doi.org/10.3201/eid1006.030972.

14. Lian J, Jin X, Hao S, Jia H, Cai H, Zhang X, et al. Epidemiological, clinical, and virological characteristics of 465 hospitalized cases of coronavirus disease 2019 (COVID-19) from Zhejiang province in China. Influenza Other Respir Viruses. 2020;14:564-74. http://dx.doi.org/10.1111/irv.12758.

15. de Lusignan S, Dorward J, Correa A, Jones N, Akinyemi O, Amirthalingam G, et al. Risk factors for SARS-CoV-2 among patients in the Oxford Royal College of General Practitioners Research and Surveillance Centre primary care network: a cross-sectional study. Lancet Infect Dis 2020;20:1034-42. https://doi.org/10.1016/S1473-3099(20)30371-6.

16. Teich VD, Klajner S, Almeida FAS, Dantas ACB, Laselva CR, Torritesi MG, et al. Epidemiologic and clinical features of patients with COVID-19 in Brazil. Einstein (Sao Paulo). 2020;18:eAO6022. https://doi.org/10.31744/einstein_journal/2020ao6022.

17. Scully EP, Haverfield J, Ursin RL, Tannenbaum C, Klein SL. Considering how biological sex impacts immune responses and COVID-19 outcomes. Nat Rev Immunol. 2020;20:442-7. https://doi.org/10.1038/s41577-020-0348-8.

18. Kopel J, Perisetti A, Roghani A, Aziz M, Gajendran M, Goyal H. Racial and Gender-Based Differences in COVID-19. Front Public Health. 2020;8:418. https://doi.org/10.3389/fpubh.2020.00418.

19. Gebhard C, Regitz-Zagrosek V, Neuhauser HK, Morgan R, Klein SL. Impact of sex and gender on COVID-19 outcomes in Europe. Biol Sex Differ. 2020;11:29. https://doi.org/10.1186/s13293-02000304-9.

20. Pinna G. Sex and COVID-19: A Protective Role for Reproductive Steroids. Trends Endocrinol Metab. 2020;S1043-2760(20)30222-8. https://doi.org/10.1016/j.tem.2020.11.004.

21. Robbiani DF, Gaebler C, Muecksch F, Lorenzi JCC, Wang Z, Cho A, et al. Convergent antibody responses to SARS-CoV-2 in convalescent individuals. Nature. 2020;584:437-42. https://doi.org/10.1038/s41586-020-2456-9.

22. Zhao J, Yuan Q, Wang H, Liu W, Liao X, Su Y, et al. Antibody Responses to SARS-CoV-2 in Patients With Novel Coronavirus Disease 2019. Clin Infect Dis. 2020;71:2027-34. https://doi.org/10.1093/cid/ciaa344.

23. Seow J, Graham C, Merrick B, Acors S, Steel KJA, Hemmings O, et al. Longitudinal evaluation and decline of antibody responses in SARS-CoV-2 infection. MedRxiv . 2020;2020.07.09.20148429. https://doi.org/10.1101/2020.07.09.20148429.

24. Amanat F, Stadlbauer D, Strohmeier S, Nguyen THO, Chromikova V, McMahon M, et al. A serological assay to detect SARS-CoV-2 seroconversion in humans. MedRxiv 2020;2020.03.17.20037713. 
https://doi.org/10.1101/2020.03.17.20037713.

25. Patel MM, Thornburg NJ, Stubblefield WB, Talbot HK, Coughlin MM, Feldstein LR, Self WH. Change in Antibodies to SARS-CoV-2 Over 60 Days Among Health Care Personnel in Nashville, Tennessee. JAMA. 2020;324:1781-2. https://doi.org/10.1001/jama.2020.18796

26. Demonbreun AR, McDade TW, Pesce L, Vaught LA, Reiser NL, Bogdanovic E, et al. Patterns and persistence of SARS-CoV-2 IgG antibodies in a US metropolitan site. medRxiv. 2020;18:2020.11.17.20233452. https://doi.org/10.1101/2020.11.17.20233452.

27. Ozaras R, Ozdogru I, Yilmaz AA. Coronavirus disease 2019 re-infection: first report from Turkey. New Microbes New Infect. 2020;38:100774. https://doi.org/10.1016/j.nmni.2020.100774

28. Chen Z, John Wherry E. T cell responses in patients with COVID-19. Nat Rev Immunol. 2020;20:52936. https://doi.org/10.1038/s41577-020-0402-6..

29. Altmann DM, Boyton RJ. SARS-CoV-2 T cell immunity: Specificity, function, durability, and role in protection. Sci Immunol. 2020;5:eabd6160. https://doi.org/10.1126/sciimmunol.abd6160.

30. Ni L, Ye F, Cheng ML, Feng Y, Deng YQ, Zhao H, et al. Detection of SARS-CoV-2-Specific Humoral and Cellular Immunity in COVID-19 Convalescent Individuals. Immunity. 2020;52:971-7.e3. https://doi.org/10.1016/j.immuni.2020.04.023.

31. Wang Y, Wang Y, Chen Y, Qin Q. Unique epidemiological and clinical features of the emerging 2019 novel coronavirus pneumonia (COVID-19) implicate special control measures. J Med Virol. 2020;92:568-76. https://doi.org/10.1002/jmv.25748.

32. Lee YL, Liao CH, Liu PY, Cheng CY, Chung MY, Liu CE, et al. Dynamics of anti-SARS-Cov-2 IgM and IgG antibodies among COVID-19 patients. J Infect. 2020;81:e55-e58. https://doi.org/10.1016/j.jinf.2020.04.019.

33. Ye Q, Wang B, Mao J. The pathogenesis and treatment of the 'Cytokine Storm' in COVID-19. J Infect. 2020;80:607-13. https://doi.org/10.1016/j.jinf.2020.03.037.

34. Lin L, Luo S, Qin R, Yang M, Wang X, Yang Q, et al. Long-term infection of SARS-CoV-2 changed the body's immune status. Clin Immunol. 2020;218:108524. https://doi.org/10.1016/j.clim.2020.108524.

35. Klein SL, Pekosz A, Park HS, Ursin RL, Shapiro JR, Benner SE, et al. Sex, age, and hospitalization drive antibody responses in a COVID-19 convalescent plasma donor population. J Clin Invest. 2020;130:6141-50. https://doi.org/10.1172/JCl142004.

36. Castelo-Branco C, Soveral I. The immune system and aging: a review. Gynecol Endocrinol. 2014;30:16-22. https://doi.org/10.3109/09513590.2013.852531.

37. Sadighi Akha AA. Aging and the immune system: An overview. J Immunol Methods. 2018;463:21-6. https://doi.org/10.1016/j.jim.2018.08.005.

38. Bonafè M, Prattichizzo F, Giuliani A, Storci G, Sabbatinelli J, Olivieri F. Inflamm-aging: Why older men are the most susceptible to SARS-CoV-2 complicated outcomes. Cytokine Growth Factor Rev. 2020;53:33-7. https://doi.org/10.1016/j.cytogfr.2020.04.005. 
39. Vallinoto ACR, da Silva Torres MK, Vallinoto MC, Cayres Vallinoto IMV. The challenges of COVID-19 in the Brazilian Amazonian communities and the importance of seroepidemiological surveillance studies. Int J Equity Health. 2020;19:140. https://doi.org/10.1186/s12939-020-01256-7. 